\title{
Pseudocyphellae ontogeny and thallus anatomy in species of Punctelia Krog (Parmeliaceae, lichenized Ascomycota)
}

\author{
Camila Aparecida Zanetti ${ }^{*}$, Suzana Bissacot Barbosa', Sérgio Akira Adachi' and Marcelo Pinto Marcelli²
}

Received: November 28, 2016

Accepted: January 17, 2017

\begin{abstract}
The genus Punctelia has been traditionally characterized by the type and distribution of pseudocyphellae, medullary chemical substances and the shape of conidia, whereas its species have been distinguished using mainly the shape, location, abundance and size of pseudocyphellae. Given that Punctelia is not monophyletic, additional studies are needed to determine its current delimitation. The present study used conventional techniques for structural studies using optical and scanning electron microscopy in order to describe and compare the structure and ontogeny of the pseudocyphellae of five species of Punctelia. The main differences among the studied species involve the type of pseudocyphellae development, the presence or absence of an epicortex cover and the organization and structure of the upper cortex. In one group of species the pseudocyphellae are formed from the outside to the inside of the thallus; in the other group, pseudocyphellae formation begins with the organization of medullary hyphae into circular groups in specific places. The present study contributes to the understanding of the structure and ontogeny of pseudocyphellae.
\end{abstract}

Keywords: aeroplectenchyma, lichen anatomy, light microscopy, Parmeliaceae, plectenchyma, pseudocyphellae, Punctelia

\section{Introduction}

Punctelia is a relatively small genus in Parmeliaceae, which comprises about 45 species (Canêz 2009; Canêz \& Marcelli 2010). Organisms of these species have a grey upper surface, punctiform pseudocyphellae, produce unciform to filiform conidia, giroforic and lecanoric acids as medullary substances, and have Africa and South America as their centers of speciation (Elix 1993; Crespo et al. 2004). The identification of Punctelia species is based mainly on the shape, location, abundance, and size of pseudocyphellae (Canêz 2009).
Pseudocyphellae are pores, 0.1 to $2 \mathrm{~mm}$ in diameter, located on the thallus surfaces of many foliose and fruticose lichens. These pores may be filled by ascending medullary hyphae, which can be projected towards the upper thallus surface. Upon inadequate gas exchange in specific regions on the thallus, the cortex splits, forming a pore, which restores the equilibrium between gas exchange and metabolic requirements of the lichen (Hale 1981).

The pseudocyphellate species of Parmeliaceae have a uniform cortical layer, except the pseudocyphellae formation (Hale 1981). However, detailed ontogenetic studies are still needed to provide a complete understanding of the development of this structure (Barbosa 2009). Cortical cells

\footnotetext{
${ }^{1}$ Departamento de Botânica, Instituto de Biociências, Universidade Estadual Paulista "Júlio de Mesquita Filho", 18618-970, Botucatu, SP, Brazil ${ }^{2}$ Seção de Micologia e Liquenologia, Instituto de Botânica, 04301-902, São Paulo, SP, Brazil

*Corresponding author: camilazanetti11@yahoo.com.br
} 
have gelatinized thick walls, are invariably agglomerated, and lack interstices or small passages that could facilitate gas exchange (Hale 1981).

Besides Punctelia, three other genera are pseudocyphellate in Parmeliaceae: Cetrelia (with laminal pseudocyphellae on the upper surface, prosoplectenchymatous upper cortex, rod-shaped conidia, and alectoronic, anziaic and divaricatic acids as medullary acids), Plasmatia (pseudocyphellae on the upper or lower surface, atranorin, caperatic, and fumarprotocetraric acids and rod-shaped conidia), and Parmelia s.s. (efigurate pseudocyphellae, rarely punctiform, rod-shaped conidia, chloroatranorin associated with atranorin in the upper cortex) (Canêz 2009; Culberson \& Culberson 1968). Among all the pseudocyphellate genera, only Punctelia occurs in Brazil (Canêz 2009). Considering that it is not a monophyletic genus, Punctelia needs additional studies to clarify its current delimitations, which are largely based on morphological and chemical characteristics (Crespo et al. 2004; 2010). Anatomical studies for the group remain lacking (Barbosa 2009).

Considering the significantly large morphological variations within the genus, the importance of pseudocyphellae for the identification of species and the lack of anatomical studies, we aimed to describe and compare the structure and ontogeny of pseudocyphellae in Punctelia species and determine if the anatomical variations found in the thallus and in the pseudocyphellae of Punctelia could be used in taxonomic studies.

\section{Materials and methods}

We analyzed anatomical aspects and pseudocyphellae development of five Punctelia Krog species: P. colombiana Sérusiaux, $P$. constantimontium Sérusiaux, $P$. graminicola (Bouly de Lesdain) Egan s.l., P. imbricata Marcelli, Jungbluth \& Elix, and P. roseola Jungbluth, Marcelli and Elix. The material studied was obtained from samples deposited in the Scientific Herbarium Maria Eneyda P. Kauffmann Fidalgo (SP) of the Instituto de Botânica, São Paulo, Brazil (Tab. 1). Samples were collected from the young distal regions (near the margin), as well as from the proximal and more developed regions (near the center of the thallus).

For light microscopy analyses, samples were prepared according to Barbosa et al. (2009) for Parmeliaceae. Samples were fixed in formalin-acetic acid-alcohol 50 (FAA 50) (Johansen 1940) for 48 hours, dehydrated in a graded ethanol series, and embedded in methacrylate resin (Leica ${ }^{\circledR}$ Historesin). Transverse and longitudinal sections (2-5 $\mu \mathrm{m}$ thick) were obtained using a rotary microtome with steel knife and stained with $0.05 \%$ toluidine blue $\mathrm{O}, \mathrm{pH}$ 4.7 (O’ Brien et al. 1964). Sections were mounted on glass slides with synthetic resin and covered with coverslips. Images were acquired using a Zeiss microscope coupled to an Olympus camera, with and without polarized light. Cell measurements were obtained with the Cell B Program - Olympus.

For scanning electron microscopy analyses, air-dried samples were attached to aluminum stubs, coated with gold (10 nm), and examined under a Quanta 200 scanning electron microscope (FEI Company, FEI, Gräfelfing, Germany) at $20 \mathrm{kV}$.

\section{Results}

\section{Thallus differentiation [Fig. 1)}

The thallus margin of the studied species was characterized by small, dense, in division and nondifferentiated fungal cells, followed by the algal layer, which also presented dividing algal cells (Fig. 1A). The similarities in the characteristics of fungal cells in this region made distinguishing of the lower cortices from the upper difficult.

The elongation zone was located between the meristematic region and the central part of older thalli. It was stratified and formed by the upper cortex, algal layer, medulla, and lower cortex. The upper cortex comprised large round cells, forming a paraplectenchymatous tissue, and the algal cells, with a smaller number of divisions. (Fig. 1B, D).

The most central and completely differentiated thallus region was characterized by the thick upper cortex, where the lichen senescence occurred, and dead cells from both bionts could be observed.

Table 1. List of species of Punctelia studied.

\begin{tabular}{|l|c|c|}
\hline Species & Material & Municipality/State \\
\hline Punctelia colombiana & L.S. Canêz \& A.A. Spielmann 964 & Vacaria/RS \\
\hline P. constantimontium & A.A. Spielmann \& L.S. Canêz 1000 & Sinimbu/RS \\
\hline P. aff. constantimontium & L.S. Canêz \& A.A. Spielmann 1038 & Vacaria/RS \\
\hline P. graminicola & A.A. Spielmann \& L.S. Canêz 978 & Sinimbu/RS \\
\hline P. aff. graminicola 1 & L.S. Canêz \& A.A. Spielmann 150 & Vacaria/RS \\
\hline P. aff. graminicola 2 & L.S. Canêz \& A.A. Spielmann 151 & Vacaria/RS \\
\hline P. imbricata & L.S. Canêz \& A.A. Spielmann 430 & Vacaria/RS \\
\hline P. roseola & P. Jungbluth 1079 & Campo Limpo Paulista/SP \\
\hline
\end{tabular}




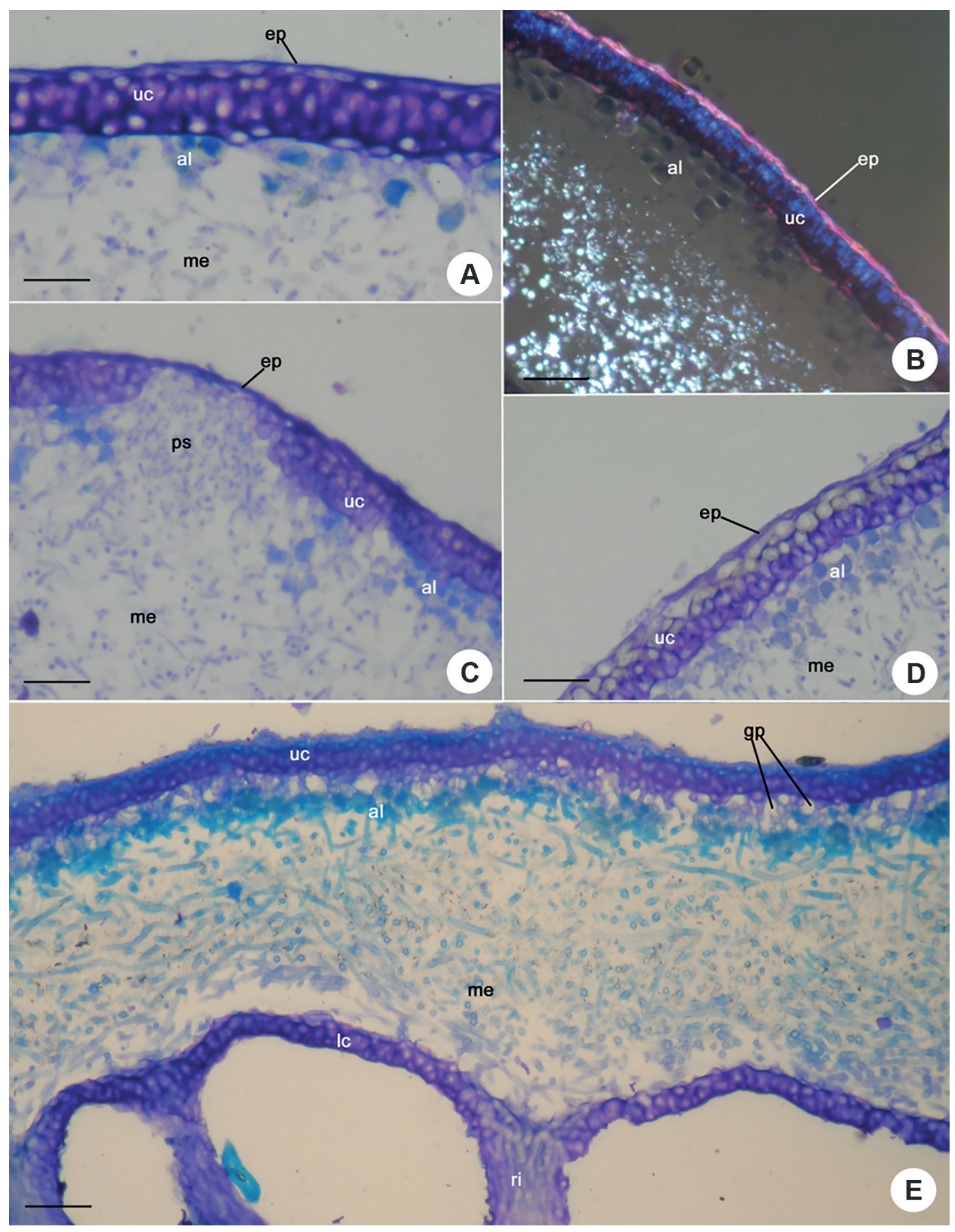

Figure 1. Transversal section of Thallus structure. A. Punctelia. aff. graminicola 2 showing epicortex, upper cortex and medulla. B. P. aff. graminicola 2 viewed under polarized light showing the epicortex with pinkish glow. C. P. graminicola showing the persistent epicortex on the pseudocyphellae. D. P. roseola showing upper cortex structure formed by three cell layers. E. P. aff. graminicola 1 showing the formation of big gaps (aeroplectenchyma) right under the upper cortex and the distinct coloration when stained with Toluidine blue, epicortex - purple, the first cell layer of the upper cortex - light blue, the other cells of the upper cortex, the hyphae of the medulla and the lower cortex - purple, the algal cells - greenish and the hyphae in the algal layer - light blue. (ep: epicortex, uc: upper cortex, me: medulla, al: algal layer, lc: lower cortex, ri: rhizine, ps: pseudocyphellae, gp: gap). Scale bars: $50 \mu \mathrm{m}$. 


\section{Thallus structure (Fig. 1]}

All studied species had a paraplenctenchymatous upper cortex covered by a thin epicortex (Fig. 1A). In $P$. aff. graminicola 2, the epicortex appeared with a pinkish glow under polarized light, which was not observed in other species (Fig. 1B). In P. constantimontium and P. graminicola, the epicortex was continuous on the pseudocyphellae (Fig. $1 C$ ), whereas in other studied species (P. colombiana, P. aff. graminicola $1, P$. aff. graminicola 2, P. imbricata and P. roseola), the epicortex was ruptured, leaving no vestige over the pseudocyphellae.

The upper cortex was well-developed in all species, and was 3-7 cells thick, depending on the thallus size. The cortex always had at least two cell layers; the upper layer was formed by small rounded cells, located immediately under the epicortex, which was extremely adherent, and the lower one, which could be differentiated into two or more layers of larger cells and thickened walls with gelatinous appearance (Fig. 1D). Thus, the upper cortex was bistratified in P. aff. graminicola 1, P. imbricata and P. roseola, and formed by three cell layers in P. colombiana, P. constantimontium and P. graminicola and $P$. aff. graminicola 2.

In P. colombiana, $P$. aff. graminicola 1 and $P$. roseola, large gaps (aeroplectenchyma) were present under the upper cortex, in the region in contact with the algal layer (Fig. 1E, Tab. 2).

Upon staining with toluidine blue $\mathrm{O}$, the first cell layer of the upper cortex and the hyphae in the algal layer of $P$. aff. graminicola 1 appeared light blue. The rest of the upper cortex, the epicortex, the medulla, and the lower cortex stained purple and the algal cells appeared greenish in color.

The thickness of the medulla varied according to the species; P. colombiana had a thicker medulla (80.0-130.0 $\mu \mathrm{m}$ wide), whereas $P$. imbricata had a thinner medulla (50.0$100.0 \mu \mathrm{m}$ wide). In all species, the horizontal medullary hyphae were predominant with the presence of vertical hyphae in the upper region of the medulla.

The rhizines were completely covered by a cortical layer in $P$. colombiana, $P$. graminicola and $P$. aff. graminicola 1 , and $P$. roseola (Fig. 1E). However, in the other species characterized (P. constantimontium, $P$. aff. graminicola 2, P. imbricata), the cortex was only present at the base of rhizines.

\section{Pseudocyphellae ontogeny and structure (Figs. 2, 3)}

The analyzed species showed two types of pseudocyphellae formation.

In $P$. colombiana, $P$. aff. graminicola 1 and $P$. aff. graminicola 2 , and P. roseola, the pseudocyphellae were formed from the outside to inside of the thallus, i.e., they were formed from the rupture and disintegration of the upper cortex cells, exposing the medullary hyphae (Fig. 2A-D, Tab. 2).

However, in P. constantimontium, P. graminicola and $P$. imbricata, the pseudocyphellae were formed from the inside to outside of the thallus. The pseudocyphellae were formed from medullary hyphae organized in circular groups at specific sites of the thallus (Fig. 3A, Tab. 2). These groups of hyphae pushed the algal cells towards the upper cortex, rupturing the cortex and the epicortex, thus exposing the medullary hyphae (Fig. 3B, C, E, F). As a result, the cortical cells disintegrated, thus enlarging the pseudocyphellae (Fig. 3B, C, E, F).

In both cases, the pore size gradually increased due to the peripheral disintegration of cells and additional intrusions of medullary hyphae. In P. roseola, the medullary hyphae formed soredia when associated to algal cells.

Pseudocyphellae hyphae were different from other medullary hyphae because they were smaller, more irregularly grouped, and covered by an amorphous material.

\section{Discussion}

The marginal region, characterized by dividing hyphae and algal cells, is considered a meristematic region responsible for thallus growth (Fig. 1A). The young and the most developed regions of the thallus differ mainly in their cortical thicknesses, presence or absence of aeroplectenchyma, and the presence and size of pseudocyphellae (Barbosa 2009).

The main differences found among the studied species were related to the type of pseudocyphellae formation, presence or absence of epicortex cover, and the organization and structure of the upper cortex. The internal thallus development was similar in all studied species and is consistent with that reported by Honegger $(1993 ; 2008)$ and Barbosa \& Marcelli (2010).

Table 2. Main anatomical features of Punctelia

\begin{tabular}{|c|c|c|c|c|c|}
\hline & & \multicolumn{2}{|c|}{ Pseudocyphellae } & \multirow[t]{2}{*}{ Upper cortex } & \multirow[t]{2}{*}{ Aeroplectenchyma } \\
\hline & & Ontogeny & Epicortex & & \\
\hline P. colombiana & & From outside to inside & Absent & 3 layers & Present \\
\hline P. constantimontium & & From inside to outside & Present & 3 layers & Absent \\
\hline P. graminicola & 150 & From inside to outside & Absent & 3 layers & Absent \\
\hline P. aff. graminicola 1 & 151 & From outside to inside & Absent & 2 layers & Present \\
\hline P. aff. graminicola 2 & 430 & From outside to inside & Absent & 3 layers & Absent \\
\hline P. imbricata & & From inside to outside & Absent & 2 layers & Absent \\
\hline P. roseola & & From outside to inside & Absent & 2 layers & Present \\
\hline
\end{tabular}




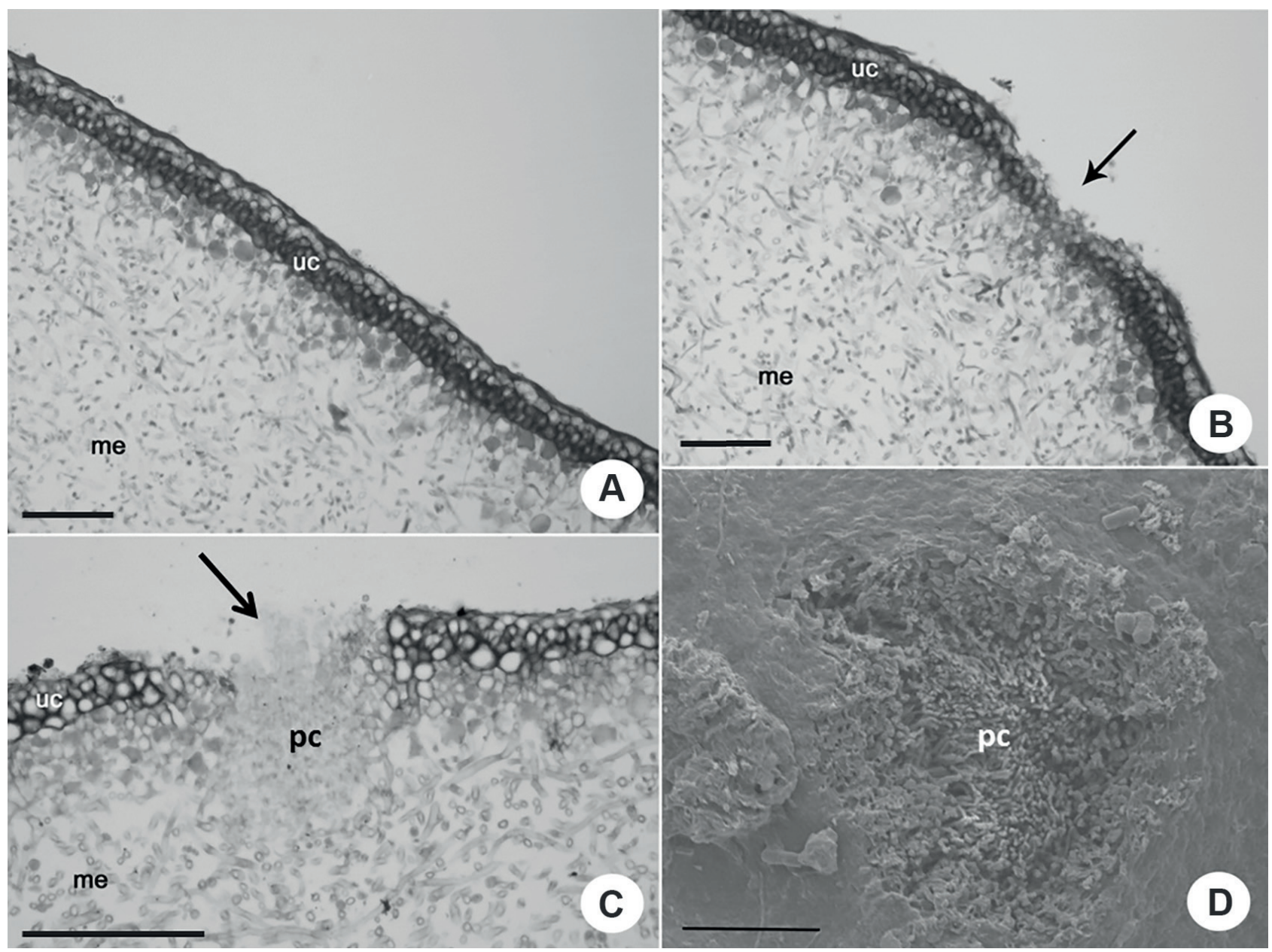

Figure 2. Pseudocyphellae ontogeny and structure - Transversal section of $P$. roseola showing the pseudocyphellae formed from the outside to inside of the thallus. A. and B. Initial stage of pseudocyphellae formation showing the rupture of the upper cortex (arrow). C. Posterior stage showing the disintegration of the upper cortex cells, exposing the medullary hyphae (arrow). D. Pseudocyphellae (arrow) viewed under scanning electron microscopy. (ep: epicortex, uc: upper cortex, me: medulla, al: algal layer, pc: pseudocyphellae, lc: lower cortex, ri: rhizine). Scale bars: $50 \mu \mathrm{m}$.

The pseudocyphellae formation begins with the cortical disintegration of the external surface, and proceeds inward the thallus (Beltman 1978). Hale (1981), on the other hand, proposed that the disintegration may start immediately above the algal layer, and may move upward until the thin polysaccharide layer (epicortex) breaks.

The mechanism that triggers the cortex disintegration and stimulates the medullary hyphae, however, is still unknown, but it has been suggested that the cortex begins to break down and forms pores at particular sites in the thallus, where gas exchange is poor. The pores help to restore the equilibrium between gas exchange and lichen metabolic needs (Hale 1981).

In P. constantimontium and P. graminicola, the epicortex was present above the pseudocyphellae (Fig. 3D) in the young region and also in the developed portion of the thallus. However, according to literature, only Parmelia species have an epicortex covering the pseudocyphellae (Hale 1981; Krog 1982; Galloway \& Elix 1983). When the epicortex persists over the pseudocyphellae, perforations develop, forming angular marks typical of the Parmelia saxatilis group and Platismatia (Hale 1981). In the species of Punctelia, and in Cetrelia olivetorum, the epicortex breaks and the hyphae are pushed over the surface, carrying the remaining cortex, and sometimes leaving a margin, which may disappear. Galloway \& Elix (1983) also showed that in Punctelia species, the pseudocyphellae do not have an epicortex covering. In the other species studied $(P$. colombiana, $P$. aff. graminicola $1, P$. aff. graminicola $2, P$. imbricata and $P$. roseola), the epicortex desitegrates, leaving no vestiges above the pseudocyphellae.

In pseudocyphellate species, the cortical layer is completely uniform, and there are no other passages besides the pores (Hale 1981). However, in P. colombiana, $P$. aff. graminicola 1 and $P$. roseola, the formation of aeroplectenchyma occurs, which was also observed in species of Canomaculina (Barbosa \& Marcelli 2010), now assigned to Parmotrema (Blanco et al. 2005). The formation of 

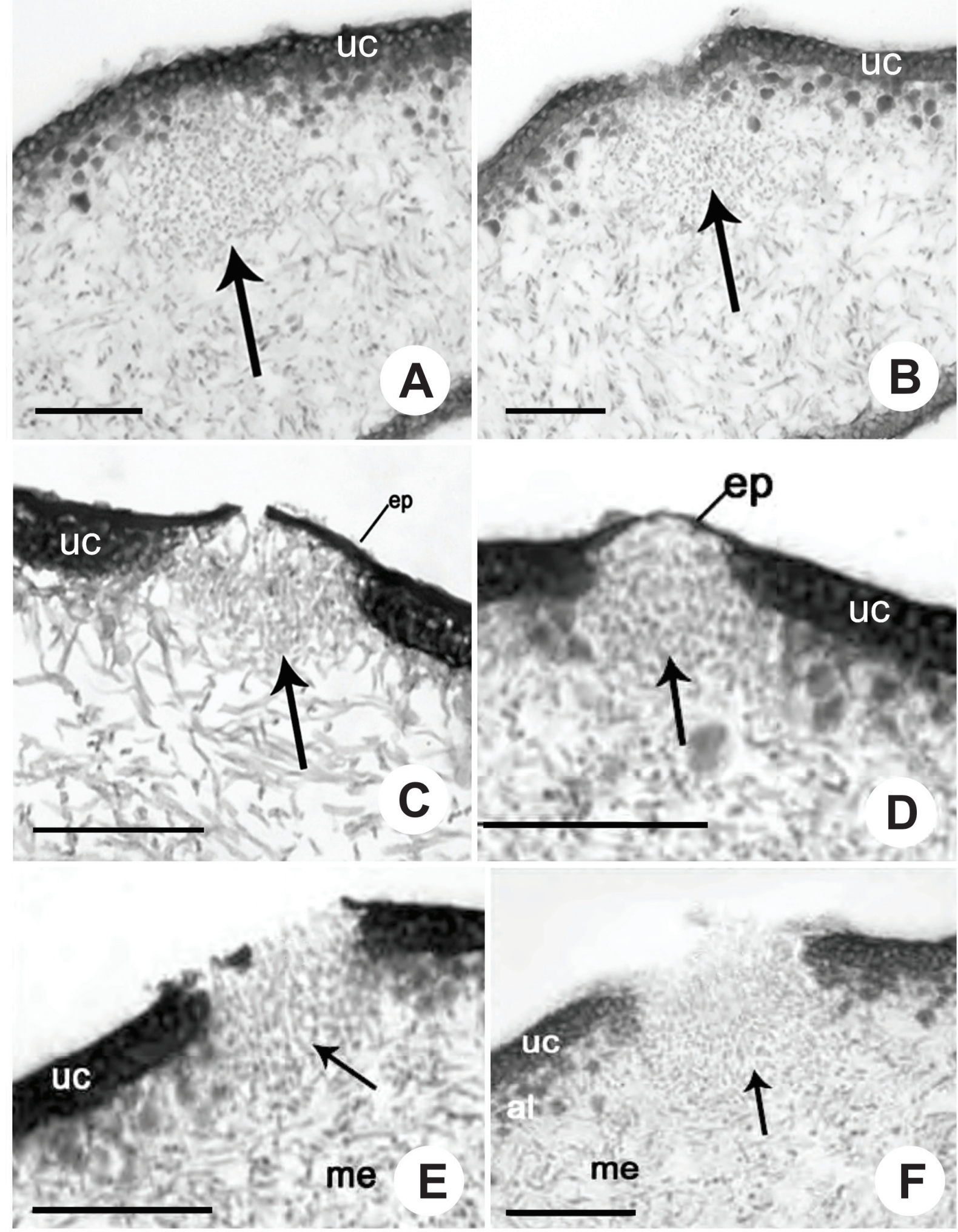

Figure 3. Pseudocyphellae ontogeny and structure - Transversal section showing the pseudocyphellae formed from the inside to outside of the thallus. A-C. P. constantimontium. A. Medullary hyphae organization in circular groups in specific sites of the thallus (arrow). B. Hyphae groups (arrow) pushing the algal cells away. C. Posterior stage showing the rupture of the upper cortex, exposing the medullary hyphae and persistent epicórtex. D-F. P. imbricata. D. Hyphae groups (arrow) pushing the algal cells away. E and F. Rupture of the upper cortex and epicortex, exposing the medullary hyphae. (ep: epicortex, uc: upper cortex, me: medulla, al: algal layer, lc: lower cortex). Scale bars: $50 \mu \mathrm{m}$. 


\section{Pseudocyphellae ontogeny and thallus anatomy in species of Punctelia Krog (Parmeliaceae, lichenized Ascomycota]}

aeroplectenchyma next to the algal cells can be related to the need for internal diffusion of gases during photosynthesis in regions where the thallus cortex becomes thicker (Barbosa \& Marcelli 2010).

Traditionally, it is believed that lichen thallus aeration occurs through pores and gaps in the upper cortex or through loose medullary hyphae (Hale 1981). However, the presence of aeroplectenchyma indicates that other possible auxiliary forms exist for thallus aeration in these species.

The description present in the literature for $P$.graminicola varies greatly in terms of its morphology (Canêz 2005; 2009). The anatomical differences between the studied specimens of $P$. graminicola, such as the number of layers in the upper cortex, the presence or absence of aeroplectenchyma, the type of pseudocyphellae, formation and the presence or absence of epicortex covering, indicate that they may be distinct species with similar morphological characteristics.

The genus Punctelia lacks anatomical studies, and phylogenetic studies that include Brazilian species have been carried out. The most recently reported phylogenies mainly focus on specific groups or species (Blanco et al. 2004; Crespo et al. 2004; 2010; Lendemer \& Hodkinson 2010; Alors et al. 2016), and the circumscription of the genus remains unestablished. Anatomical studies have proven to be important, supplying additional data for the group distinction. Moreover, our results contribute to the taxonomic studies on Punctelia and provide auxiliary information for group taxonomy and future phylogenetic studies.

\section{Acknowledgements}

We thank the Coordenação de Aperfeiçoamento de Pessoal de Nível Superior - CAPES - Brazil for the PhD grant to C. A. Zanetti and for the fellowship to S. B. Barbosa (PNPD project $n^{\circ}$ 02749/09-2), to Conselho Nacional de Desenvolvimento Científico e Tecnológico - CNPq - Brazil for the research grant to M. P. Marcelli, to the technical staff of Centro de Microscopia Eletrônica - IBB, UNESP, and to L.S. Canêz for the assistance provided during the development of this work.

\section{References}

Alors D, Lumbsch TH, Divakar PK, Leavitt SD, Crespo A. 2016. An integrative approach for understanding diversity in the Punctelia rudecta species complex (Parmeliaceae, Ascomycota). PLoS ONE 11(2): e0146537. doi:10.1371/journal.pone.0146537.
Barbosa SB. 2009. Aplicabilidade taxonômica de variações anatômicas em fungos liquenizados. $\mathrm{PhD}$ Thesis, Universidade Estadual Paulista "Júlio de Mesquita Filho", Botucatu.

Barbosa SB, Marcelli MP. 2010. Cortical diversity in three species groups of Parmotrema sensu lato (Parmeliaceae, lichenized Ascomycota). Micron 41: 861-869.

Barbosa SB, Marcelli MP, Machado SR. 2009. Evaluation of different protocols for anatomical studies in Parmeliaceae (lichenized Ascomycota). Micron 40: 218-225.

Beltman HA. 1978. Vegetative structuren der Parmeliaceae und ihre entwicklung. Bibliotheca Lichenologica 2: 1-193.

Blanco O, Crespo A, Elix JA, Hawksworth DL, Lumbsch HT. 2004. A molecular phylogeny and a new classification of parmelioid lichens containing Xanthoparmelia-type lichenan (Ascomycota, Lecanorales). Taxon 53: 959-975

Blanco O, Crespo A, Divakar PK, Elix JA, Lumbsch HT. 2005. Molecular phylogeny of parmotremoid lichens (Ascomycota, Parmeliaceae). Mycologia 97: 150-159.

Canêz LS. 2005. A família Parmeliaceae na localidade de Fazenda da Estrela, município de Vacaria, Rio Grande do Sul, Brasil. MSc Thesis, Instituto de Botânica, São Paulo.

Canêz LS. 2009. Estudos taxonômicos em Punctelia (Parmeliaceae, Ascomycetes Liquenizados). PhD Thesis, Instituto de Botânica, São Paulo.

Canêz LS, Marcelli MP. 2010. The Punctelia microsticta-group (Parmeliaceae). The Bryologist 113: 728-738.

Crespo A, Divakar PK, Arguello A, Gasca C, Hawksworth DL. 2004. Molecular studies on Punctelia species of the Iberian Peninsula, with an emphasis on specimens newly colonizing Madrid. The Lichenologist 36: 299-308

Crespo A, Kauff F, Divakar PK, et al. 2010. Phylogenetic generic classification of parmelioid lichens (Parmeliaceae, Ascomycota) based on molecular, morphological and chemical evidence. Taxon 59: 1735-1753.

Culberson WL, Culberson CF. 1968. The lichen genus Cetrelia and Platismatia (Parmeliaceae). Contributions from the United States National Herbarium 34: 446-558.

Elix JA. 1993. Progress in the generic delimitation of Parmelia sensu lato lichens (Ascomycotina: Parmeliaceae) and a synoptic key to the Parmeliaceae. The Bryologist 96: 359-383.

Galloway DJ, Elix JA. 1983. The lichen genera Parmelia Ach. and Punctelia Krog, in Australasia. New Zealand Journal of Botany 21: 397-420.

Hale ME. 1981. Pseudocyphellae and pored epicortex in the Parmeliaceae: their delimitation and evolutionary significance. The Lichenologist 13: 1-10.

Honegger R. 1993. Developmental biology of lichens. New Phytologist 125: 659-677.

Honegger R. 2008. Morphogenesis. In: Nash III TH. (ed.) Lichen biology. Cambridge, Cambridge University Press. p. 69-93.

Johansen DA. 1940. Plant microtechnique. New York, Mc Graw-Hill Book Company.

Krog H. 1982. Punctelia, a new lichen genus in the Parmeliaceae. Nordic Journal of Botany 2: 287-292.

Lendemer JC, Hodkinson BP. 2010. A new perspective on Punctelia subrudecta (Parmeliaceae) in North America: previously rejected morphological characters corroborate molecular phylogenetic evidence and provide insight into an old problem. The Lichenologist 42: 405-421

O’Brien TP, Feder N, McCully ME. 1964. Polychromatic staining of plant cell walls by toluidine blue O. Protoplasma 63: 443-478. 